\title{
Når man køber en idé uden at forstå den
}

Af Peter Beyer *)

\section{A. Indledning}

\section{Baggrund}

Denne artikel er en opfølgning på casebeskrivelsen ”Kampen om den organisatoriske selvfortælling" (find den her: https://rauli.cbs.dk/index.php/SiS/article/download/5567/6184), hvor der blev stillet en række en række spørgsmål til læserne. Artiklen her giver en række mulige svar på de stillede spørgsmål, samt en kort gennemgang af den teori, der fører frem til de givne svar.

På CBS arbejder vi ofte med følgende grundmodel, når vi skal løse problemer:

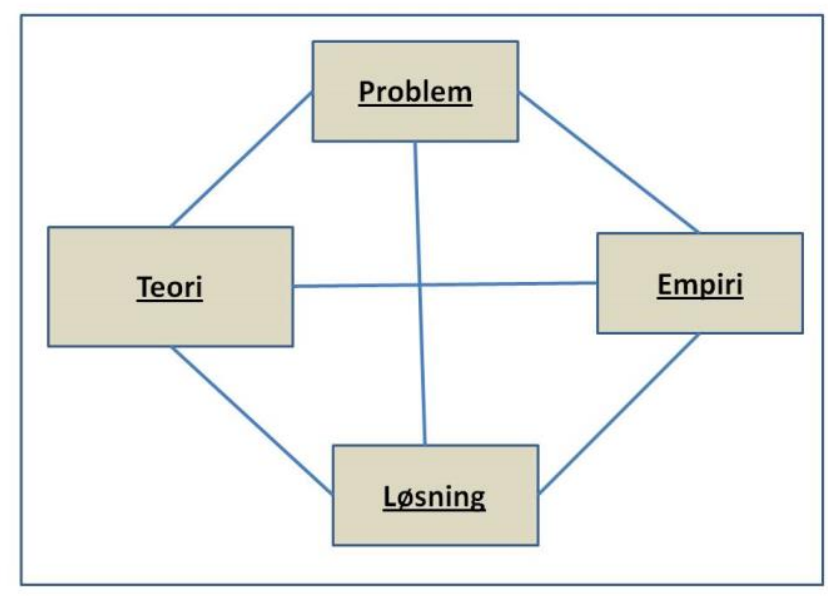

Figur 1: Koncept for problemlosning.

Figuren illustrerer følgende: Vi formulerer et problem, som vi vil finde en løsning på. Derefter

*) Peter Beyer er akademiingeniør, ph.d. og ekstern lektor på Institut for Produktion og Erhvervsøkonomi ved CBS 
undersøger vi hvilke data, vi kan indsamle, og som belyser det problem, vi gerne vil have løst. Jo flere relevante data, vi kan få indsamlet, og jo flere synsvinkler vi kan anlægge på problemet, jo bedre. Dernæst skal vi finde teori, modeller, metoder, værktøjer, etc., som med udgangspunkt i de data og synsvinkler, vi har indsamlet, kan føre frem til en løsning af problemet.

Casen bestod i gennemførelsen af et projekt defineret af opdragsgiveren. Her var problemet givet, ligesom løsningen også var specificeret. Derimod var der ikke taget stilling til teori, ligesom der i udgangspunktet ikke var empiri tilgængeligt for tilbudsgiver.

Problemet var formuleret som: skab og implementer en ny organisatorisk selvfortælling, der kan frigive energi, positive tanker og stolthed omkring arbejdspladsen, og skabe en fælles følelse blandt medarbejderne, der kan vise, at vi alle er vigtige.

Løsningen var formuleret som et $3^{*} 1$ uges internatkursus for 31 instruktører, som kan sætte dem i stand til at forestå uddannelse af kommunens 6.500 medarbejdere, således at kommunen efterfølgende selv kan forankre en ny organisatorisk selvfortælling.

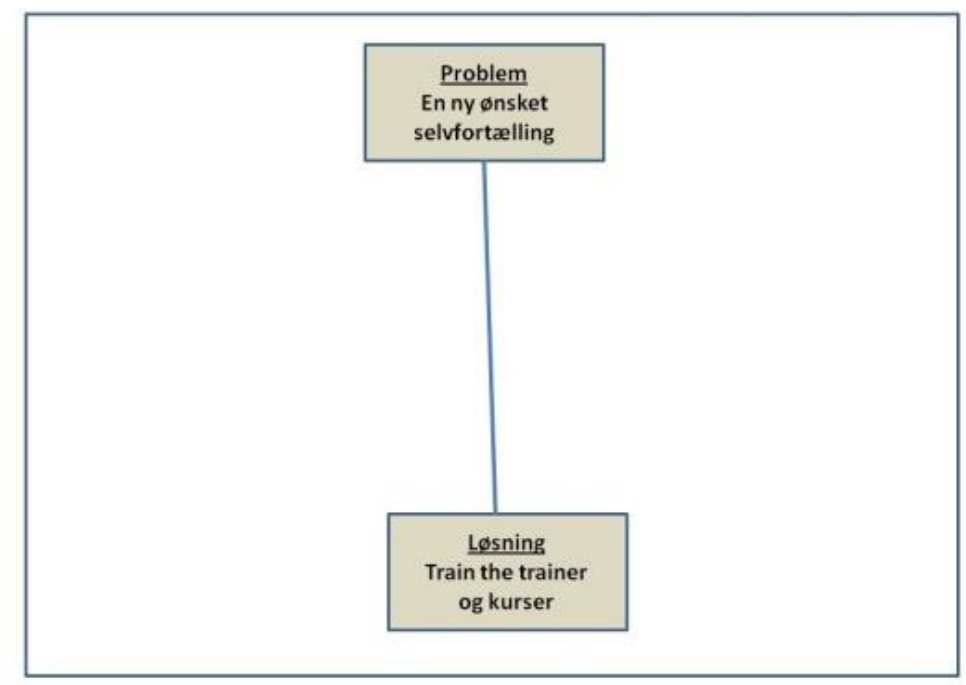

Figur 2: Problemløsningskonceptet som det så ud i udbudsmaterialet.

Udgangspunktet for opgaven var således, at problemet, der skulle løses samt løsningen, var specificeret i udbudsmaterialet, hvorimod vi som tilbudsgivere ikke havde tilgængelig empiri, og derfor heller ikke i udgangspunktet anden metodeovervejelse, end at der ville være tale om en 
kontinuert forandringsproces, samt et ønske om en større frisætning af medarbejderne. I tilbuddet lagde vi derfor op til følgende:

Teori: Her valgte vi at arbejde med frisætning af medarbejderne (en IY styringsmodel) og med kontinuerte forandringer, se afsnit 2. Metoder og modeller.

Empiri: Her ville vi basere os på de selvfortællinger, vi kunne identificere i de to første faser af projektforløbet.

Projektets blev derfor designet med følgende aktivitetsforløb:

a. Forberedelse af Uddannelsesforløbet (FRYSNING).

1. Opstartsmøde med direktionen.

2. Diagnose (en kommunal selfie).

3. Opstilling af projektets succeskriterier.

4. Formulering af en vision og et fælles værdigrundlag.

5. Afholdelse af mobiliseringsmøder.

b. Gennemførelse af uddannelsesforløbet (REBALANCERING).

1. Gennemførelse af instruktøruddannelse.

2. Medarbejderkurser (Her var vi ikke med).

3. Gennemførelse af et byrådsseminar.

c. Evaluering af uddannelsen (OPTØNING).

1. Virkningsevaluering.

2. Efterspillet. 
Konceptet kom derefter til at se således ud:

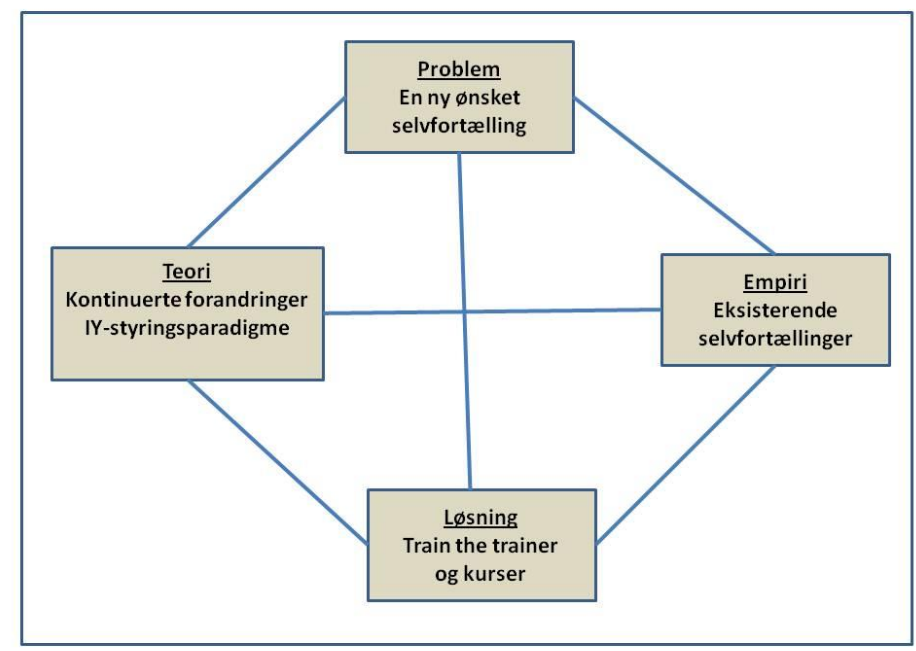

Figur 3: Problemlosningskonceptet som det kom til at se ud i tilbudsmaterialet.

\section{Oversigt over artiklen}

Denne artikel skal læses i forlængelse af artiklen "Kampen om den organisatoriske selvfortalling", der stiller en række spørgsmål til læseren. Artiklen her giver et muligt svar på disse spørgsmål, den er disponeret på følgende måde:

- Afsnit B beskriver de vigtigste metoder og modeller, som ligger bag den angrebsvinkel, der blev brugt i casen, samt de forudsætninger, som angrebsvinklen bygger på. De mulige svar i afsnit $\mathrm{E}$ bygger på disse forudsætninger.

- Afsnit C beskriver i kort form den organisatoriske selvfortælling, som den var ved projektets start, selvfortællingen som man ønskede at komme frem til og endelig den selvfortælling, man endte med. Afsnittet kan ses som en kortfattet beskrivelse af forløb og resultat.

- Afsnit D er en kort opsummering af de barrierer, som ikke blev adresseret i forløbet.

- Afsnit E indeholder derefter et muligt svar på de i casen stillede spørgsmål. 


\section{B. Metoder og modeller}

\section{Den organisatoriske selvfortælling}

Når vi vil forklare og forstå os selv og vores omverden, spiller fortællinger en central rolle. En fortælling er en vinklet fremstilling af et handlings-/hændelsesforløb eller en årsagssammenhæng med en tilnærmet fortælling. Der er altså tale om en praktisk formet beskrivelse af sandheden.

Vi bruger forskellige fortællinger til at skabe mening. De fortællinger, vi anvender, giver en forklaring på, hvordan de ting, vi oplever, hænger sammen, hvordan vi forholder os til dem, hvad der er rigtigt og vigtigt, og hvordan forskellige personer placerer sig i fortællingen. Pointen er, at vi forstår vores liv ved hjælp af forskellige fortællinger, men at disse netop ikke fremstår som fortællinger, men som en del af vores virkelighedsopfattelse.

Beskriver vi f.eks. bombetogter i Afghanistan som humanitære aktioner og ikke som egentlige krigshandlinger, eller beskriver vi krigen i Irak som en befrielse snarere end en invasion, ja så vil mange af os formentlig mene, at det er en sand beskrivelse. I realiteten er det en særlig fortælling om, hvordan verden hænger sammen. Vores beskrivelser af virkeligheden fortæller os, at afghanerne og irakerne er i nød og undertrykkes og derfor må hjælpes. En fortælling indebærer en række forestillinger om, hvad en masse forskellige begivenheder handler om, hvad årsagerne til dem er, hvem der i den forbindelse er helte og skurke, samt hvilke mål og forhindringer, de præsenterer. Det er netop det, der gør fortællingen attraktiv: Den tilbyder en enkel forklaring på det indviklede.

Fortællingerne forvandler et kompleks anliggende med en masse indviklede politiske og økonomiske sammenhænge og interesser, til en simpel og ligetil affære: Det handler om frihed contra ikke-frihed; det handler om undertrykte mennesker og deres befriere. Fortællinger tilbyder således ikke bare en opskrift på, hvad der må gøres, og hvem der må gøre det. Den tilbyder også en forklaring på, hvorfor og hvordan de må gøre det: Hvilke interesser og hensigter, de handler ud fra. Der tages udgangspunkt i, at fortællinger ikke er objektive, men hænger tæt sammen med vores kulturelle bagage og måden, vi lever vores liv på. Fortællinger beskriver virkeligheden fra et særligt perspektiv. Det er derfor interessant, hvilke fortællinger vi bruger, fordi dette ofte er afgørende for, hvordan vi handler, hvordan vi forstår andres handlinger, og hvad vi synes er rigtigt og forkert, sandt eller falskt. 
Gennem de fortællinger, vi udveksler med hinanden, bringer vi orden i vores verden, vi finder meningen i andre menneskers handlinger og "forhandler" os til rette med hinanden, om hvordan verden skal forstås. Virkeligheden er noget, vi oplever, fordi vi i et givet lokalt fællesskab er blevet enige om at opleve den sådan. Om børn har godt af at få klø, om internationale uoverensstemmelser skal behandles som krigserklæringer, om Gud hedder Allah, er noget vi lokalt er blevet enige om, fordi det giver god mening i det fællesskab, vi virker i. Fortællinger er menneskers måde at fortælle hinanden, hvad det vil sige at leve og virke i de givne omstændigheder.

Ønsket i casen var at skabe rammerne for en fælles organisatorisk fortælling. Det indebar, at de nødvendige forudsætninger i forløbet var: tilgængelige muligheder, passende handlinger, der kan realiseres, kommunikation som sikrer dialog og samarbejde, og alt dette skal integreres og have en troværdig kobling til virkeligheden.

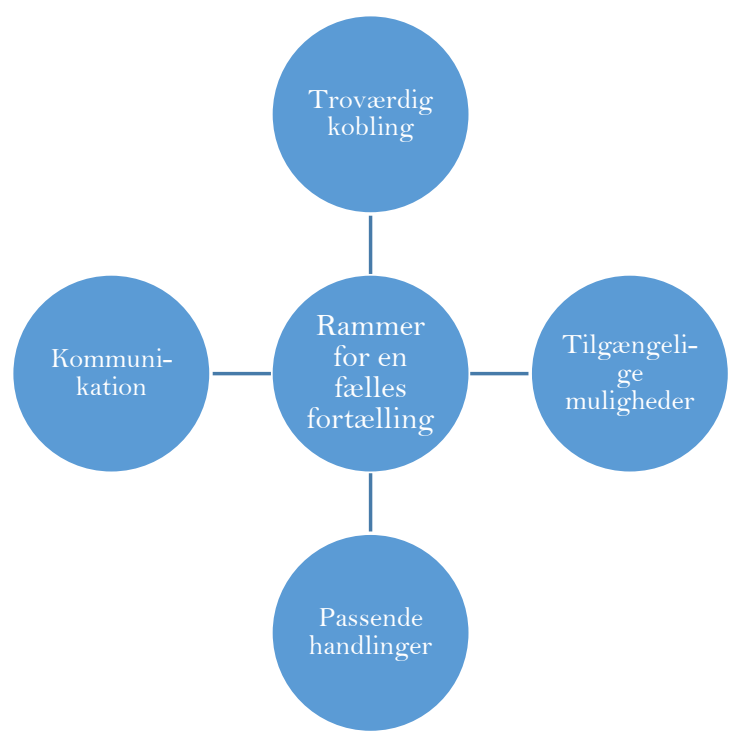

Figur 4. En felles organisatorisk selvfortalling forudsatter, at kommunikationen og interaktionen mellem magtsystem og medarbejdere foregår på en sådan måde, at medarbejderne kan skrive sig ind $i$ den falles fortalling, og at rammerne er på plads.

\section{Organisationen som løst koblet system}

En kommune kan betragtes som et løst koblet system. Det indebærer, at interaktionen mellem de forskellige enheder i kommunen er sporadisk, præget af tilfældigheder og svingende i indhold. Det indebærer også, at enhederne hver især opretholder deres eget særpræg. 
I ethvert system er bindingen inden for et delsystem stærkere end mellem delsystemerne. Løst koblede delsystemer er oftest kendetegnet ved, at der ikke er en stærk enighed om præferencer og årsags- virkningssammenhænge. I en kommune er delsystemerne de forskellige forvaltninger. Ændringsprocessen i kommunen sker derfor ikke i forhold til et stabilt organisationsmiljø, hvor forandringer kan planlægges og styres. Den foregår inden for et netværk, hvor den vil konkurrere med eller indgå i sammenhæng med andre initiativer.

Weick og Quinn (1999) ser forandringen i løst koblede systemer som kontinuerte forandringer, hvor man omdirigerer det, der allerede er på vej i organisationen. Derfor bliver ledelsen meningsskabere, der udpeger mønstre og ændrer deres rammer, demonstrerer hvordan tilsigtede ændringer kan ske i mindre spring, fjerner blokader for improvisering, oversættelse og læring og ændrer mening gennem nyt sprog, rigere dialog og ny identitetsformulering.

\section{Kontinuerte forandringer}

Weick og Quinn skelner mellem episodiske forandringer og kontinuerlige forandringer. For kontinuerlige forandringer vender de Lewins forandringsmodel “optø, ændre, frys” på hovedet. Når forandringer sker løbende, er udfordringen ikke først at "optø” organisationen, men at se mønstre og tendenser i det, der allerede foregår. Ved kontinuerlige forandringer er det derfor mere hensigtsmæssigt med rækkefølgen "frys, rebalancer, optøning”.

\begin{tabular}{|c|c|c|}
\hline & Episodisk forandring. & Kontinuert forandring. \\
\hline Organisationsbilledet. & $\begin{array}{l}\text { Organisationen er stabil. } \\
\text { Forandringer er planlagte, } \\
\text { diskontinuerte og igangsatte. }\end{array}$ & $\begin{array}{l}\text { Organisationen er løst koblede } \\
\text { meningsstrukturer. } \\
\text { Forandringen er et løbende } \\
\text { læringsforløb med mange } \\
\text { mindre forandringer. }\end{array}$ \\
\hline Forandringsbilledet. & $\begin{array}{l}\text { Forandringen er et designet } \\
\text { forløb fra en veldefineret stabil } \\
\text { tilstand til en anden veldefineret } \\
\text { stabil tilstand. } \\
\text { Interventionsstrategier: }{ }^{1} \\
\text { 1. Teknisk rationel. } \\
\text { 2. Humanistisk. } \\
\text { 3. Politisk. }\end{array}$ & $\begin{array}{l}\text { Forandringen er en } \\
\text { omfortolkning af den } \\
\text { organisatoriske virkelighed. } \\
\text { Interventionsstrategi: } \\
\text { - Eksplorativ. }\end{array}$ \\
\hline
\end{tabular}

\footnotetext{
${ }^{1}$ Se Beyer (2018) og Borum (2013)
} 


\begin{tabular}{|c|c|c|}
\hline Interventionsstrategi. & $\begin{array}{l}\text { 1. Teknisk rationel }=>\text { analyse, } \\
\text { design, implementering. } \\
\text { 2. Humanistisk => optø, ændre, } \\
\text { frys. } \\
\text { 3. Politisk => drømme, fælles } \\
\text { byggeproces, etabler } \\
\text { ejerskab. }\end{array}$ & $\begin{array}{l}\text { Eksplorativ => frys, } \\
\text { rebalancer, optø. } \\
\text { Changemakere, der anerkender } \\
\text { og sætter fokus på de } \\
\text { eksisterende mønstre og } \\
\text { organisatoriske } \\
\text { selvfortællinger. } \\
\text { Arbejder med at ændre } \\
\text { selvfortællingerne gennem } \\
\text { Talk the Walk og åbner for } \\
\text { improvisering, ny forståelse og } \\
\text { læring. }\end{array}$ \\
\hline Lederrolle. & $\begin{array}{l}\text { Primus motor der igangsætter } \\
\text { forandring. }\end{array}$ & $\begin{array}{l}\text { Sensemaker, der faciliterer } \\
\text { forandring. }\end{array}$ \\
\hline
\end{tabular}

Tabel 1: Forskellen mellem episodiske forandringer og kontinuerlige forandringer.

Interventionsstrategien i casen kan resumeres således:

a. FASTFRYS: En ændring af de organisatoriske selvfortællinger vil kræve, at vi først gør dem synlige for alle i organisationen og i særdeleshed for magtsystemet.

b. REBALANCER: Her genfortolkes de organisatoriske selvfortællinger. Vi søger i fællesskab at skabe nye fælles selvfortællinger, som vil give mening, dvs. at de fører frem til en situation, hvor vi alle, såvel medarbejdere som ledere og politikere får os selv med over som hele mennesker.

c. OPTØNING: Her lader man de forskellige dele af kommunen vælge egne handlinger, og handle, med udgangspunkt i den ønskede nye selvfortælling. Lederne skal nu turde sætte sensemaking og sensegiving fri individuelt og kollektivt. Dette betyder dog ikke, at der ikke er retning og rammer (jævnfør figur 4). 


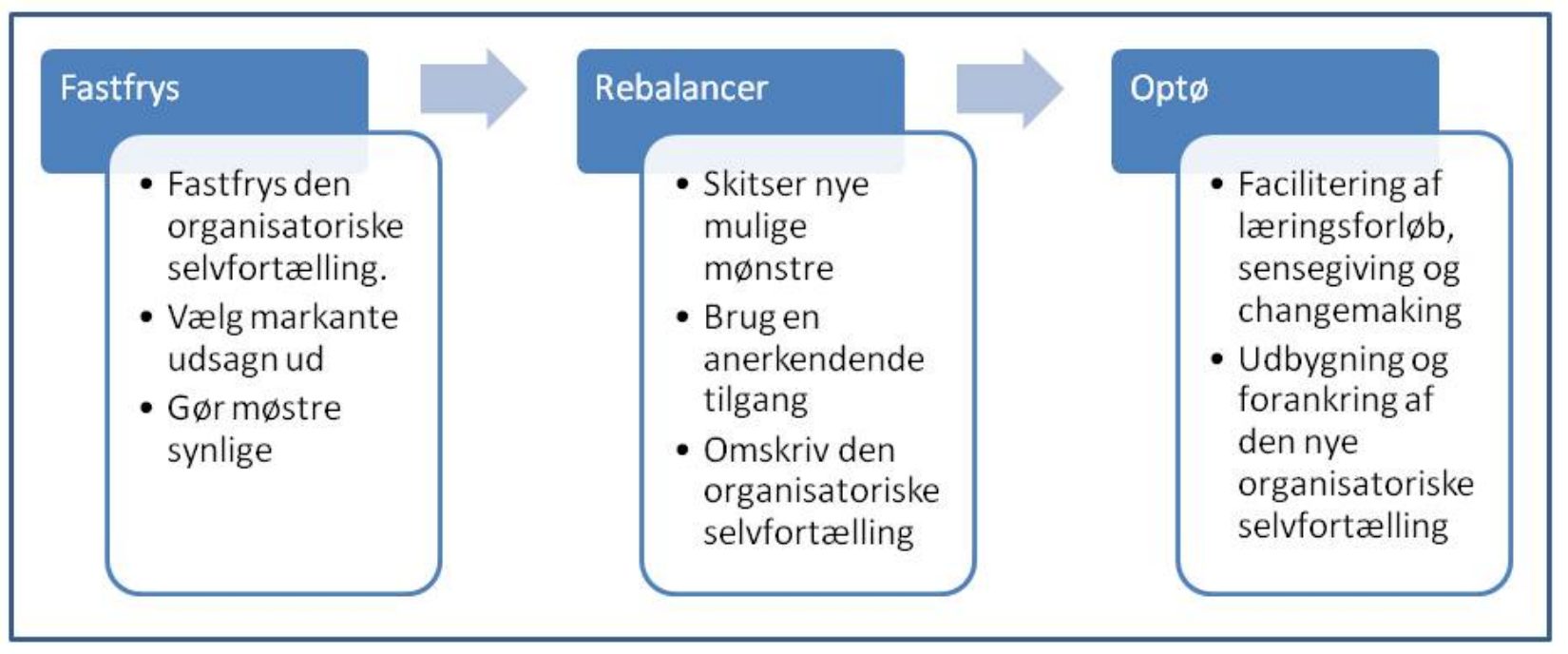

Figur 5: Interventionsstrategien ved kontinuerte forandringer.

\begin{tabular}{|c|c|}
\hline Rebalancering & Optøning \\
\hline $\begin{array}{l}\text { Proces der sigter på at strukturere og forbedre } \\
\text { debat og dialog. Ønsket er at integrere } \\
\text { forskellige synspunkter blandt ligebyrdige og } \\
\text { frie deltagere med henblik på at hjælpe dem } \\
\text { med at forudsige og kontrollere ændringer i }\end{array}$ & $\begin{array}{l}\text { Opgaven er at forstå, hvordan systemet og dets } \\
\text { institutioner og reguleringspraksisser begrænser } \\
\text { aktørerne samt at intervenere for at frigøre } \\
\text { aktørerne og sikre tillidsbaseret selvorganisering. }\end{array}$ \\
\hline $\begin{array}{l}\text { "deres" system også i uldne situationer, hvor } \\
\text { der ikke er fodslag omkring færdige } \\
\text { målsætninger. }\end{array}$ & $\begin{array}{l}\text { Sigter på at identificere og fjerne de barrierer der } \\
\text { begrænser læring og udvikling af relationer. }\end{array}$ \\
\hline Sigter på læring og udvikling af relationer. & $\begin{array}{l}\text { Forståelse af ændringsdynamikken ved at tage } \\
\text { udgangspunkt i aktørernes intentioner i feltet. }\end{array}$ \\
\hline
\end{tabular}

Tabel 2: Forskellen mellem rebalancering og optoning.

\section{De kommunale styringsmodeller.}

En styringsmodel omfatter antagelser om årsags- virkningsforhold, standarder for praksis og adfærd, samt specifikke eksempler, som beskriver, hvordan en organisation bør styres, når den skal gøre ting.

Kommunernes opgaveløsning omfatter dels standardiserede, regelbaserede ydelser, og dels Individuelle producerede og leverede ydelser. Det indebærer, at kommunerne er nødt til at kunne 
leve med to forskellige styringsmodeller: S. Y. modellen for håndtering af de standardiserede regelbaserede ydelser og I. Y. modellen for håndtering af de individuelle producerede og leverede ydelser.

Styringsmodellen S. Y. indebærer, at styring, budgettering og tildeling, produktion og levering af ydelserne er standardiseret, og kontrolleret centralt på baggrund af objektive kriterier.

Styringsmodellen I. Y. indebærer, at kontrol med styring, tildeling, produktion og levering af ydelserne i så vid udstrækning som muligt er lagt i hænderne på fagprofessionelle på baggrund af deres skøn, og forankret i faglige normer, etik og værdier.

I artiklen "Fra åben konflikt til symbiotisk evolution: Hvordan offentlige ledere forener fagprofessionel autonomi og hård budgetdisciplin” beskriver Pedersen og Aagaard, hvordan ledelser kan løse det traditionelle organisatoriske dilemma, der ofte opstår mellem de to forskellige styringsmodeller.

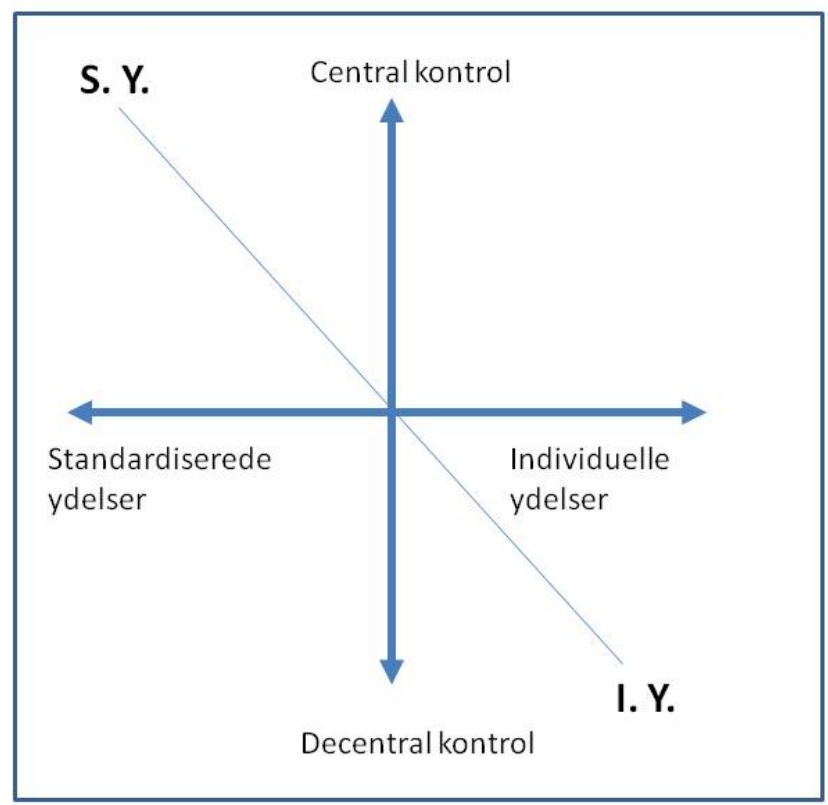

Figur 6: De to styringsparadigmer er divergerende. Jo mere S.Y., jo mindre I. Y. og omvendt.

John Storm Pedersen og Peter Aagaard argumenterer for, at hvis det skal lykkes både at holde budgetterne og at opretholde de fagprofessionelles autonomi, så må lederne løbende deltage i den organisatoriske tale. 


\section{a. Frisatning af medarbejderne.}

Ifølge serviceloven bør mange af de kommunale ydelser tildeles på grundlag af individuelle skøn foretaget af fagprofessionelle. Derfor bør de fagprofessionelle gøres til partnere i en fortsat dialog om produktion, levering og tildeling af ydelserne.

Den måde kommunens ansatte fungerer på er centralt i kommunens opgaveløsning. Michael Lipsky (1980) hævder, at kommunen "tegnes” af de medarbejdere, der i sidste ende står for at gennemføre opgaveløsningen i praksis. Derfor skal disse ses som en central del af styringsmodellen.

Kommunens medarbejdere har ofte at gøre med et stort antal klienter, tvetydige mål, knappe ressourcer. Når det kombineres med faglig diskretion og behovet for at fortolke reglerne fra sag til sag, kan forskellen, mellem byrådets politik og politikkens udmøntning i praksis være betydelig og bekymrende.

Den problemstilling Lipsky ser, har baggrund i de begrænsede ressourcer sammenholdt med de løbende prioriteringsovervejelser. I kommunens udkant har medarbejderne måske en anden mening om opgavernes udførelse, der ikke stemmer overens med de retningslinjer, der er udstukket i byrådet. Ofte er situationerne for komplekse til at kunne behandles efter strenge og formelle regler, men kræver professionel faglig indlevelse.

Dilemmaet for medarbejderne er, at de formodes at træffe beslutninger om borgerne på grundlag af de konkrete sager, men strukturen i deres job gør dette umuligt. På grund af strukturen i jobbet tvinges de til at indføre praksiselementer som timeboxing, rutinebehandling, hurtig og overfladisk klassifikation af klienterne, massebearbejdning af situationer og gummistempling.

Gummistempling indebærer, at man blindt accepterer andres domme, man refererer til andre medarbejderes vurderinger, selv om klientens situation kan være anderledes og kompliceret. Den samlede virkning, hævder Lipsky, kan bevirke en praksis, som i sidste ende kan undergrave borgernes forventninger. Dette forhold understreger vigtigheden i en stærk læringssløjfe, hvor medarbejdernes erfaringer samles op og føres tilbage til det politiske niveau, der sætter reglerne og udformer politikkerne. Lipsky hævder, at medarbejderne har et kendskab til praksis og en klarere forståelse af klienterne, som bør samles op og udnyttes. 
Det indebærer, at lederne bør udvikle en praksis, som har til hensigt at skabe konvergens mellem logikkerne S. Y. og I. Y. Denne praksis består af følgende 3 hovedelementer

1. Lederne bør deltage i alt lige fra dialog om succeskriterier, faglige standarder, værktøjer, politiske krav, drift effektivitet og effekten af ydelserne på borgernes velfærd.

2. Lederne bør stille udfordrende spørgsmål til de fagprofessionelles daglige praksis.

3. Lederne bør arbejde på at udvikle denne dialog til en beslutningsorienteret dialog.

\section{Magtsystemet som sensegivere og changemakere}

\section{a. Sensemaking}

Begrebet sensemaking (Weick 1995) beskriver, hvordan aktørerne i en organisation hele tiden er i gang med at skabe mening. Der er 7 betingelser, som skal være til stede, for at der kan skabes mening. De 7 betingelser er følgende:

1. Mening er forbundet med konstruktion af identitet, og den personlige selvfortælling.

2. Mening skabes baglæns (retrospektivt).

3. Mening bliver synlig, når noget sættes I værk.

4. Meningsdannelse sker i en social kontekst.

5. Meningsskabelse er en fortløbende proces.

6. Mening bliver ansporet af stikord fra referencerammer.

7. Mening er drevet af troværdighed frem for nøjagtighed.

Mening skabes på alle niveauer, dvs. på individuelt niveau, afdelingsniveau og organisatorisk niveau. Den mening, vi forsøger at skabe, bliver skabt gennem det sprog, vi bruger, og den måde, vi handler på. Meningsdannelsen har udgangspunkt i aktørernes selvfortællinger og dermed også i den organisatoriske selvfortælling.

At fremstå som kompetente fagprofessionelle betyder, at de individuelle selvfortællinger og den organisatoriske selvfortælling ikke er konstante, men størrelser, som er i kontinuerlig forandring. Når selvfortællingerne ændrer sig, så ændres ligeledes medarbejderne syn på verdenen. Weick taler her om, at individets fornemmelse for at ændre og tilpasse sig, er afhængig af tre forskellige behov: 
1. Behov for selvhævdelse og for at opbygge en positiv og sammenhængende selvfortælling.

2. Behov for at fremstå som kompetent og effektiv.

3. Behov for at opleve kontinuitet og sammenhæng.

Selvfortællingen vil således både i meningsdannelse og organiseringsprocesser være et betydningsfuldt element for det enkelte individ.

Man kan kun tillægge en handling mening ved at se den retrospektivt. Et vigtigt point er, at aktørerne kan have mange forskellige meningsskabelser i gang, som kan være selvmodsigende i forhold til hinanden. Aktørerne kender resultaterne af handlinger, der foregår, men de har forskellige forklaringer på, hvad og hvorledes noget sker, da forklaringerne konstrueres retrospektivt. Magtsystemets meningsdannelse kan være forskellig fra medarbejdernes meningsdannelse, ligesom der kan være forskelle i meningsdannelsen i de forskellige forvaltninger.

Når informationer bliver modtaget, behandlet og anvendt, gennemgår de en proces, som kan inddeles i tre delprocesser:

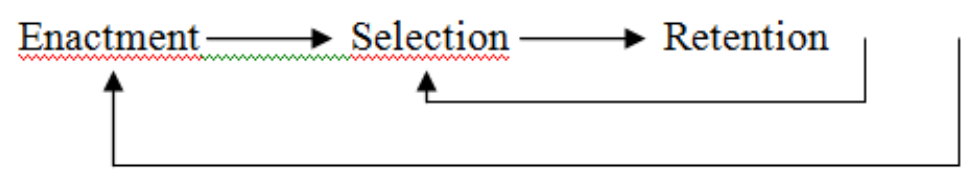

Figur 7: Forløb i sensemaking processen.

Man starter med enactment, hvor aktørerne fremhæver visse dele af informationerne og ser bort fra andre dele. Weick benytter sig af begrebet enactment for at pointere, at man selv er aktivt med til at skabe den virkelighed, man ser. Det indebærer, at alle i kommunen konstruerer deres egen virkelighed, og at de reagerer i forhold til denne.

Der foretages derefter et fravalg eller tilvalg i informationerne. Det sker i delprocessen $\underline{\text { Selection. }}$ Valget sker ved at fokusere på visse hændelser eller handlinger, som dermed bliver fundamentet for meningsskabelsen. 
Når aktørerne har konstrueret deres virkelighed, er de nødt til at reducere flertydigheder. Det gør de ud fra deres tidligere selvfortælling. Den bruges som forståelsesramme for de nye informationer. Denne sidste delproces, hvor aktørerne beslutter hvilke informationer og meninger, de vil beholde, kaldes Retention. Den får betydning for, hvilke fremtidige informationer der efterfølgende giver mening, og hvilke, der efterfølgende ses bort fra.

De sociale processer er afgørende for meningsdannelsen. I en kommune med mange forskellige fagprofessioner, opleves de sociale processer generelt stærkt dominerende. Hver faggruppe har udviklet en social kontekst, som præger deres meningsforståelse. Weick taler om, at sensemakingen er social, når aktørerne koordinerer deres handlinger. Men han fastholder samtidig, at det er gennem sprog og handlinger, vi kan forstå os selv, uanset om meningsforståelsen sker individuelt eller kollektivt.

Weick argumenterer for, at de fleste "stikord" vil være tvetydige eller vage i deres betydning. Det betyder, at konteksten, som f.eks. hvem det er, der siger "stikordet" eller karakteren af relationen mellem den talende eller lyttende, har betydning for fortolkningen.

Han taler også om planer og den betydning, som de kan have for en leders handling, og siger:

Managers keep forgetting that it is what they do, not what they plan, that explains their success. They keep giving credit to the wrong thing - namely, the plan - and having made this error, they then spend more time planning and less time acting.

Når aktørerne fortæller deres billede af virkeligheden, er kriterierne for akkurathed i det, der fortælles, noget sekundært. De historier, som fremstår som troværdige, fornuftige og sandsynlige, er de historier, man tilslutter sig. 


\begin{tabular}{|c|c|}
\hline Weick's 7 punkter: & Indhold: \\
\hline $\begin{array}{l}\text { Mening er forbundet med konstruktion af } \\
\text { identitet og den personlige selvfortælling. }\end{array}$ & $\begin{array}{l}\text { Vi skaber og tolker verden, sådan som vi ser os selv. Som } \\
\text { fagprofessionel, er det vigtigt at fremstå som værende } \\
\text { dygtig til sit fag, og til at være i stand til at kunne agere } \\
\text { professionelt i praksis. }\end{array}$ \\
\hline Mening skabes baglæns (retrospektivt). & $\begin{array}{l}\text { Først handler man, derefter forholder man sig til det, som } \\
\text { er gjort. Handlingen bliver meningsfuld i form af, at der } \\
\text { sættes ord på det, som er foregået. }\end{array}$ \\
\hline $\begin{array}{l}\text { Mening bliver synlig, når noget sættes I } \\
\text { værk. }\end{array}$ & $\begin{array}{l}\text { Man ser, hvad det er, som sker i organisationen. } \\
\text { I meningsskabelsesprocesser tror vi ofte på noget først, } \\
\text { og som følge af at vi tror på det, kan vi bagefter få øje på } \\
\text { det. }\end{array}$ \\
\hline Meningsdannelse sker i en social kontekst. & $\begin{array}{l}\text { Meningsdannelsen foregår dels hos den enkelte, men vil } \\
\text { også ske i de sociale processer og det fælles samspil, som } \\
\text { foregår blandt de fagprofessionelle og lederne imellem. }\end{array}$ \\
\hline Meningsskabelse er en fortløbende proces. & $\begin{array}{l}\text { Meningsdannelsen foregår hele tiden, men vil løbende } \\
\text { ændre sig over tid, i takt med at der sker en kontinuerlig } \\
\text { udvikling i de forskellige afdelinger i kommunen. }\end{array}$ \\
\hline $\begin{array}{l}\text { Mening bliver ansporet af stikord fra } \\
\text { referencerammer. }\end{array}$ & $\begin{array}{l}\text { Aktørerne vil se på, hvem det er, som siger eller gør } \\
\text { noget, der kan have betydning for den udvikling, som } \\
\text { foregår. } \\
\begin{array}{l}\text { Det er lettere at få øje på ting, der bekræfter vores } \\
\text { fornemmelser af, hvad der foregår, frem for de ting, der } \\
\text { udfordrer vores opfattelser. }\end{array}\end{array}$ \\
\hline $\begin{array}{l}\text { Mening er drevet af troværdighed frem for } \\
\text { nøjagtighed. }\end{array}$ & $\begin{array}{l}\text { Når et projekt fremstår som enten godt eller dårligt, vil } \\
\text { den historie, som fortælles om projektforløbet, være } \\
\text { værdifuld for forståelsen af det opnåede resultatet. }\end{array}$ \\
\hline
\end{tabular}

Tabel 3: Weicks 7 punkter.

I det følgende har vi illustreret de 7 punkter med eksempler fra casen

\begin{tabular}{|l|l|}
\hline De 7 punkter & Eksempler på udsagn fra casen \\
\hline $\begin{array}{l}\text { Mening er forbundet med konstruktion af } \\
\text { identitet, og den personlige selvfortælling. }\end{array}$ & $\begin{array}{l}\text { Kerneværdier som kvalitet og ansvar er noget, } \\
\text { man kan bruge i sin hverdag. Nu er det igen lovligt } \\
\text { at tilrettelægge arbejdet ud fra brugernes ønsker, }\end{array}$ \\
\hline
\end{tabular}




\begin{tabular}{|c|c|}
\hline & $\begin{array}{l}\text { medens der tidligere var mange regler for, hvad } \\
\text { man måtte og ikke måtte. Hvis fx fru Jensen bad } \\
\text { mig om at tage nogle rundstykker med, når jeg } \\
\text { skulle møde næste morgen, så måtte jeg i } \\
\text { princippet ikke handle for fru Jensen. Det var } \\
\text { noget, jeg bare gjorde, selv om jeg vidste, jeg ikke } \\
\text { måtte. I dag er det lovligt, og det har jeg det } \\
\text { rigtigt godt med. }\end{array}$ \\
\hline Mening skabes baglæns (retrospektivt). & $\begin{array}{l}\text { Nu igen - der er gennem årene taget mange tilløb, } \\
\text { som aldrig er blevet til noget, der er ikke tillid til, } \\
\text { at det denne gang bliver til noget. }\end{array}$ \\
\hline Mening bliver synlig, når noget sættes I værk. & $\begin{array}{l}\text { Mange ledelsesudmeldinger bliver utroværdige, } \\
\text { fordi man ikke lever op til dem. Det virker, som om } \\
\text { at direktionen ikke er engageret i projektet. } \\
\text { Projektet lyder godt, men indtil nu er det jo blot } \\
\text { tomme ord. }\end{array}$ \\
\hline Meningsdannelse sker i en social kontekst. & $\begin{array}{l}\text { Jeg kan ikke ændre på mine værdier, fordi jeg har } \\
\text { været på kursus med folk fra plejehjem og } \\
\text { vuggestuer, siger en skattemedarbejder. }\end{array}$ \\
\hline Meningsskabelse er en fortløbende proces. & $\begin{array}{l}\text { Vi bliver hørt og spurgt. Ansvaret for arbejdet } \\
\text { uddelegeret til den enkelte. Værdigrundlaget er } \\
\text { ofte til debat i vores medarbejdergruppe. }\end{array}$ \\
\hline $\begin{array}{l}\text { Mening bliver ansporet af stikord fra } \\
\text { referencerammer. }\end{array}$ & $\begin{array}{l}\text { Administrationsdirektøren lægger i en netop } \\
\text { udsendt redegørelse afstand til den aktuelle sag om } \\
\text { løbsk økonomi i projektet. Det er for mig helt } \\
\text { tydeligt, at det ikke er en samlet direktion, der står } \\
\text { bag projektet, siger } 1 \text {. viceborgmester. }\end{array}$ \\
\hline $\begin{array}{l}\text { Mening er drevet af troværdighed frem for } \\
\text { nøjagtighed. }\end{array}$ & $\begin{array}{l}\text { Drejer det sig ikke igen i sidste ende om } \\
\text { besparelser, og er lederne klar til værdibaseret } \\
\text { ledelse. }\end{array}$ \\
\hline
\end{tabular}

Tabel 4: Weicks 7 punkter illustreret med eksempler fra casen.

\section{b. Sensegiving.}

Teorien om sensemaking er udvidet med begrebet "sensegiving". Sensegiving indebærer, at sensegiveren (f.eks. en leder) forsøger at øve indflydelse på andre for at få dem til at fortolke handlinger og begivenheder på en særlig måde. Sensegiving er at påvirke aktører til at vælge nye stikord, med henblik på at skabe nye selvfortællinger. Kontinuerte forandringer kræver, at lederne 
bliver "Sensegivere, der faciliterer den ønskede forandring” snarere end opdragsgivere, der bestiller en forandring".

"Walk the talk" bliver ofte brugt i forhold til forandringer. En leder, der er sensegiver, bør gøre det, der siges, "Walk the Talk”. Weick ser det også modsat. Da sensemaking sker retrospektivt, er det svært at tale om noget, vi endnu ikke har oplevet, så det bliver troværdigt. Men hvis ledelsen evner "Talk the Walk", altså evner at italesætte vejen, samtidig med at den betræeses, så er det "Talk the Walk". Italesat handling er et godt redskab til at tydeliggøre en retning.

Set i relation til forandringsprocesser og ud fra et organisationsperspektiv handler sensegiving om at tilføje indtryk, der giver den enkelte lyst til at bevæge sig i en bestemt retning. Det mest effektive er at tale til følelserne, og der er storytelling et stærkt værktøj. At arbejde med etablering af nye organisatoriske selvfortællinger kan være et udtryk for sensegiving.

En sensegiver:

○ Fortæller det som er, som det også kunne være og giver derfor det værende et andet ansigt.

○ Skaber fælles oplevelser, som knytter organisationen sammen.

○ Investerer i fælles handlinger.

○ Lytter til medarbejderne for at træffe de rigtige beslutninger.

○ Gør beslutninger til fortolkningshandlinger snarere end politiske valg.

\section{c. Changemaking.}

Changemaking handler om løbende at tage bestik af den situation, man befinder sig i, for på den baggrund at tage stilling til, hvad det næste skridt skal være. Pointen er, at det ikke er nok at sikre, at der sker meningsskabelse i starten af processen, men at man også er nødt til løbende at facilitere meningsskabelsen.

Derfor er det vigtigt at være meget opmærksom på, hvad der sker, når forandringens nye måder at handle på bliver taget i brug, og løbende at følge op. Weick’s anvisninger er følgende:

○ Kom hurtigt i gang med at handle i overensstemmelse med forandringsformålet.

○ Saml løbende op på og skab mening om, hvad der er virknings- og meningsfuldt i den nye praksis. 
○ Brug den skabte forståelse af, hvad der virker og ikke virker til at genplanlægge, hvordan man når i mål med det, man ønsker at opnå.

Weick har følgende pointer:

- Ledelsen kan ikke alene skabe den organisatoriske selvfortælling; den kommer ud af den sociale interaktion, som lederen er en del af på lige fod med medarbejderne.

- Organisationer udvikler specifikke måder at erkende deres omgivelser på, fortolkningsprocesser er ikke tilfældige.

○ Målet er at skabe et kort, der forenkler territoriet, med henblik på at facilitere handling.

- Magten i organisationerne haves af dem, som designer de rammer, som bestemmer, hvad det betyder at tage beslutninger.

- Magten ligger i beslutningspunkterne.

Som aktør i magtsystemet kan man have forskellige præferencer. Er man kortsigtet eller langsigtet, er man individualist eller teamspiller. Afhængigt af, hvordan magtsystemet er sammensat, vil det udfolde sig på forskellige måder (Meister, 2007). Det er vigtigt, at uenigheder kommer op til overfladen, og at forskelle bliver tydelige og behandles, hvis magtsystemet skal kunne fungere som effektive changemakere.

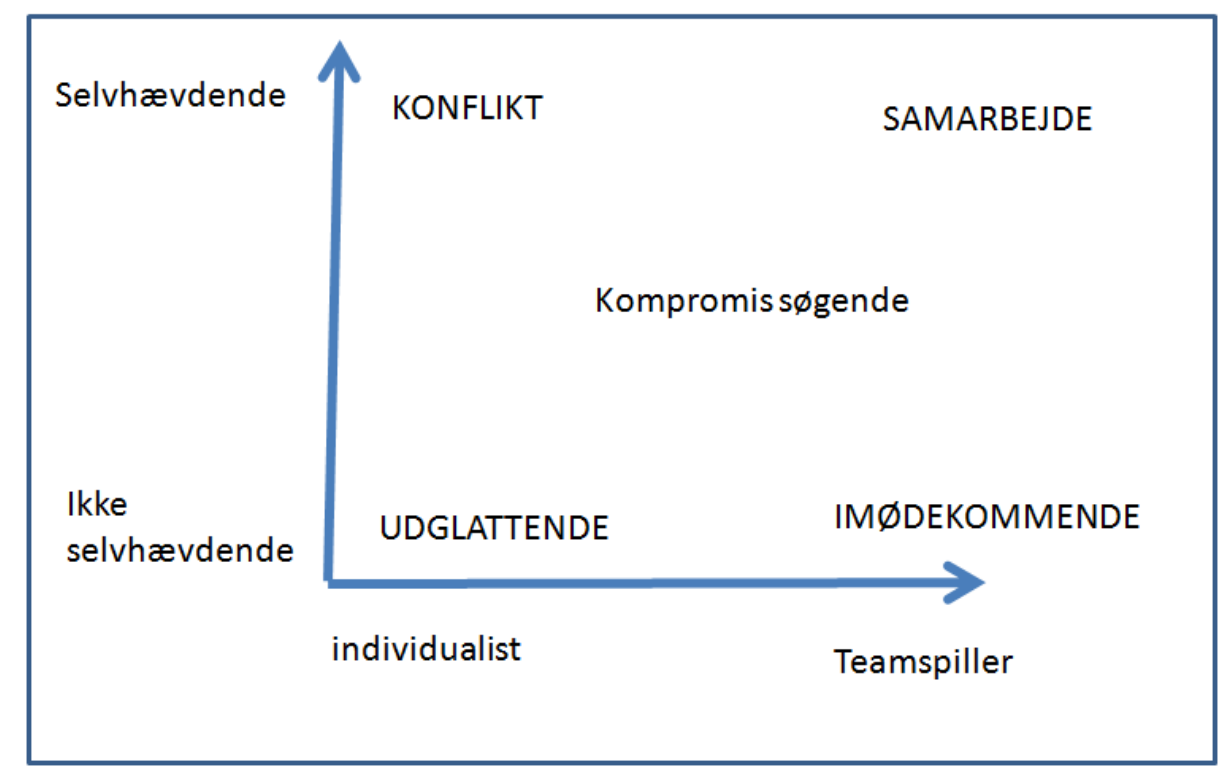

Figur 8: Forskellige former for adferd i magtsystemet afhengig af aktorernes praferencer. 
Vi kan derfor konkludere, at meningsdannelse forudsætter handling, hvor magtsystemet er nødvendigt som sensegivere og changemakere. Herunder vil man komme direkte over i dilemmaet mellem I.Y. styringsmodellen og S.Y. styringsmodellen. Dertil kommer, at meningen konstrueres i en social proces, hvor der kan være stor forskel på den mening, de forskellige fagprofessionelle i kommunen vil danne. Det betyder, at kommunernes værdibredde bliver en yderligere udfordring.

\section{Selvfortællingerne, som de var, som de var ønsket, og som de blev}

Når man læser casen, kan man se den følgende udvikling i den organisatoriske selvfortælling.

\section{Frysning: Selvfortællingen som den var}

1. Medarbejdere:

1. Vi er bange for fodfejl.

2. Magtsystemet er meget delt og gør det svært at arbejde ordentligt.

3. Ledelsesudmeldingerne er utroværdige.

4. Initiativer plejer at ebbe ud.

5. Projektet forudsætter et kulturskifte fra kontrol til tillid.

6. Der er for mange regler og for lidt værdier.

2. Magtsystem:

1. Vi har ikke fælles mål og visioner.

2. Kommunikationsprocesserne skaber problemer.

3. Vores mødekultur er ineffektiv.

4. Vi mangler anstændighed og gensidig respekt.

5. Byrådet er ineffektivt.

6. Tilliden mellem byråd og direktion er utilstrækkelig.

7. Vi håndterer økonomi med hovsaløsninger, der udløser efterfølgende slagsmål.

8. Problemer giver ofte mulighed for nulsumsspil og individuel profilering.

\section{Håndtering af værdibredden i løst koblede institutioner}

Metaforer er velegnede, når der skal skabes dialoger mellem parter, der i udgangssituationen har forskellig subkultur, fortolkninger og begreber. Når man leder efter metaforer, går man efter nogle af en anden art, end dem man er vant til at tænke i. Formålet er dobbelt, først uddrager vi 
erfaringen fra metaforen, dernæst bruger vi denne til at se på vores egen situation med nye briller. Det er en proces, der skaber kreativitet. Metaforer kan danne solide broer over sprogkløfter.

I den senere tid er der forsket en del i metaforer. Forskning viser, at kategoriseringsprocesser involverer metaforer på det mest grundlæggende niveau af den proces, hvor man organiserer sin viden i form af kognitive modeller. Begrundelsen for forskningen er behovet for at kunne integrere indsigt fra en mængde af discipliner, der sædvanligvis ikke har så meget med hinanden at gøre. Metaforer kan give det mønster, fra hvilket kategorisering og efterfølgende organisering kan foretages. De følgende metaforer illustrerer billeder, der er blevet brugt om samarbejde, her vist for at illustrere spændvidden.

\begin{tabular}{|ll|}
\hline Metafor & Metaforens mangler eks. \\
\hline $\begin{array}{l}\text { Netværk: Man sender og modtager information og } \\
\text { varer i et netværk af aktører - eksempel den } \\
\text { traditionelle logistikkæde. }\end{array}$ & $\begin{array}{l}\text { Der er kun begrænsede muligheder for } \\
\text { håndtering af konflikter og } \\
\text { interessemodsætninger. }\end{array}$ \\
\hline $\begin{array}{l}\text { Revolution: Vi begraver vores forskelligheder i en } \\
\text { fælles kamp mod en fælles fjende. }\end{array}$ & $\begin{array}{l}\text { Der er så få rammer som muligt for at sikre } \\
\text { størst mulig mobilisering - fraværet af rammer } \\
\text { øger muligheden for internt slagsmål mellem } \\
\text { parterne efter revolutionen. }\end{array}$ \\
\hline $\begin{array}{l}\text { Handel og udvikling - Gennem at udveksle ydelser i } \\
\text { et handelsforhold får begge parter fordele. }\end{array}$ & $\begin{array}{l}\text { Handelsrelationerne åbner mulighed for dårlig } \\
\text { kvalitet, mangler etc., som det kræver } \\
\text { kontraktforhold at få kontrol over. }\end{array}$ \\
\hline $\begin{array}{l}\text { Økosystemet - Koblede planter og dyr - økosystemet } \\
\text { er et godt eksempel på, hvordan forskellige arter kan } \\
\text { samarbejde i symbiose. Gaia hypotesen er udforsket } \\
\text { som en global model for samarbejde på global plan. }\end{array}$ & $\begin{array}{l}\text { Øødekæder, seksuel dominans af de stærkeste } \\
\text { arter etc. }\end{array}$ \\
\hline $\begin{array}{l}\text { Drama: Et drama kan sættes op som design for et } \\
\text { samarbejde - med scener, hvor de forskellige parter } \\
\text { bidrager med indsigt og forskellige former for }\end{array}$ & $\begin{array}{l}\text { Selv inden for drama er der forskelle på } \\
\text { hovedrolle-indehavere og statister, ligesom der } \\
\text { kvaliteter. }\end{array}$ \\
\hline $\begin{array}{l}\text { Karismatiske bevægelser - når der er religiøse og } \\
\text { publikum. }\end{array}$ & $\begin{array}{l}\text { Sådanne bevægelser indeholder en risiko for at } \\
\text { deltagerne kan blive udsat for manipulation fra } \\
\text { "falske” profeter og folkeforførere }\end{array}$ \\
\hline $\begin{array}{l}\text { Bygning - Et samarbejde kan ses som det at bygge } \\
\text { noget sammen, et hus, en have en bil eller andet. }\end{array}$ & $\begin{array}{l}\text { Hvert projekt ses i isolation uanset dets indirekte } \\
\text { sammenhæng med andre projekter og opgaver - } \\
\text { der kan derfor komme prioriteringsproblemer, }\end{array}$ \\
\hline
\end{tabular}


hvis en part midlertidigt må trække sig fra samarbejdet grundet andre prioriteringer.

Spil - Spil indebærer et betragteligt samarbejde Team opbygges for at vinde en serie af spil. mellem spillerne hvad enten der er tale om kortspil eller holdsport. Inden for holdet er succesfaktorerne teamarbejde og fokusering på interne roller og opbakning af hinanden under kriser.

Elitens konspiration - samarbejde kan ses inden for forskellige former for eliter og professioner mht. at holde gruppens status i hævd - fx det lægelige sammenhold på hospitaler etc.

Det lovregulerede felt - sammenbinding af sociale aktører i et system af lovgivning, der regulerer de forskellige relationer.
Man kan let blive ramt af $\mathrm{x} / \mathrm{y}$ teorien oligarkiets jernlov og lignende - blive bekræftet i sin egen overlegenhed.

Tabel 5: Eksempler på forskellige metaforer.

\section{a. Kollage blev brugt som metafor for den losning, der sigtes mod}

En kommune har mange institutioner og forvaltninger med hver sin subkultur og faglighed. Kommunens opgaveløsning spænder fx over: Børnehaver og vuggestuer, Skoler, Park og vej, Socialvæsnet, Beskæftigelsesområdet, Plejehjem, Sundhedscentre, Kultur, Omsorg, Politik og jura, Økonomi, Personale, IT, Borgerservice. Blot for at nævne nogle. Kollagemetaforen vil derfor være en god bro over de subkulturelle kløfter, der vil opstå under skabelsen af en ny kommunal selvfortælling.

Kollage er en individuel kunstart og helt forskelligt fra kunstarten maleri, når den dyrkes rigtigt. Kollage er en god metafor for organisering af samarbejder. Maling begynder typisk med farver, lærred og staffeli. Dette giver afgrænsningen af kunstværket. Collage derimod begynder med nogle eksisterende objekter som papir, metal, træ etc. og med en i materialet iboende struktur i tre dimensioner. Collage-kunstneren samarbejder disse irregulære materialer og former disse til et harmonisk billede. Der er ikke noget lærred eller staffeli, der giver grænserne for kunstværket. Skabelsesprocessen for en kollage tager sin egen ikke foruddefinerede retning, irregulær og tredimensionalt, underlagt betingelserne i det brugte materiale. Collagen har potentialet til at revolutionere den visuelle kunstart, men kun hvis kunstneren frigør sig fra reglerne og fladen, der er givet af den traditionelle malerkunst. 
De der har været i Budapest, vil genkende borgen på nedenstående billede. Borgen ligger i byparken og blev opført midlertidigt i anledning af tusindårsfestlighederne i 1896, hvor den skulle vise arkitekturens udvikling i Ungarn. Arkitekten Ignac Alpár lavede en syntese med enkeltheder fra 21 historiske bygninger i alle mulige stilarter. Borgkomplekset skulle egentlig rives ned efter festlighederne, men da det var så populært, blev det bygget rigtigt i alle sine stilarter.

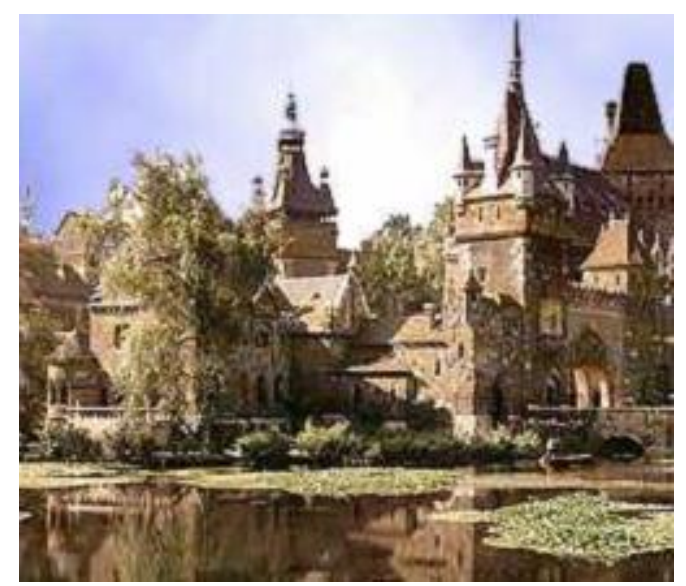

Figur 9: Vajdahunyad-borgen Det fysiske bevis på kollagens kraft.

Metaforen rejser følgende spørgsmål:

- Hvad skal sjælen i vores nye organisatoriske selvfortælling være? Hvad er det kunstneriske udtryk i metaforen?

○ Hvordan skal den eller de stykker, vi hver for sig repræsenterer, fases ind i det ønskede billede?

Når man arbejder med kollagemetaforen, bliver ledelsen og medarbejderne kunstnere, der arbejder på i fællesskab at skabe et nyt kunstværk.

Jeg spurgte engang en maler, hvad det var han gjorde, når han skabte et kunstværk. Hans svar lød således: Jeg har en dialog med lærredet. På samme måde skal ledelsen og medarbejderne have en dialog med den organisatoriske selvfortælling, medens den nye selvfortælling opstår. 


\section{Rebalancering: Den nye selvfortælling som man ønskede den}

1. Medarbejdere:

a. Vi kender og oplever kommunens vision, værdigrundlag og målsætninger som klare pejlemærker.

b. Vi demonstrerer værdierne i forbindelse med eget arbejde.

c. Vi forstår og anerkender hinandens arbejds- og kompetenceområder på tværs af kommunen.

d. Vi føler stolthed over at arbejde i kommunen.

e. Vi forstår betydningen af, at alle fungerer som kommunens ansigt udadtil.

f. Vi forstå nødvendigheden af udvikling og forandringer til glæde for samfundet.

g. Vi oplever frisættelse og selvstyring som middel til større arbejdsglæde og effektivitet.

h. Vi tager ejerskab for en ny måde at tænke og arbejde på.

i. Vi er mere fejltolerante.

2. Magtsystem:

a. Vi vil arbejde ud fra hensyn til borgere og medarbejdere frem for politisk profilering.

b. Vi arbejder med vision og strategi frem for detalje.

c. Vi medvirker i videst mulig omfang til at skabe tryghed for medarbejderne i kommunen.

d. Vi arbejder som byråd i tillid til medarbejdernes kvalitet.

e. Vi arbejder for en positiv udvikling for kommunen.

f. Vi arbejder for en kultur præget af åbenhed og ærlighed og tillid.

g. Vi arbejder ud fra fælles værdier og fælles mål.

h. Vi fungerer som ledere og ikke som kontrollører.

i. Vi viser loyalitet over for beslutninger.

j. Vi lever med fejl i den udstrækning, de giver anledning til laring.

k. Vi arbejder ud fra et positivt menneskesyn.

1. Vi giver klare udmeldinger nedad.

m. Vi arbejder for at tydeliggøre det, byrådet er enige om, og dermed hvad fundamentet er for udviklingen i kommunen de nærmeste år.

n. Vi arbejder på baggrund af en effektiv dialog. 


\section{Optøning: selvfortællingen, som den endte med at være}

1. Medarbejdere:

a. Vi arbejder som vi altid har gjort.

b. Der er fortsat fejlfokusering og kontrol.

c. Jeg kan ikke ændre på mine værdier, bare fordi jeg har været på kursus med folk fra plejehjem og børnehaver.

d. Vi har mangelfuld styring og synlig ledelse.

2. Magtsystem:

a. Vi er vendt tilbage til politiske slagsmål, mudderkastning, fejlfokusering etc.

b. Projektet har udløst individuelle profileringer og nulsumsspil.

c. Vi er ikke loyale over for vores aftaler.

d. Tilliden mellem byråd og direktion er væk.

\section{Opsummering}

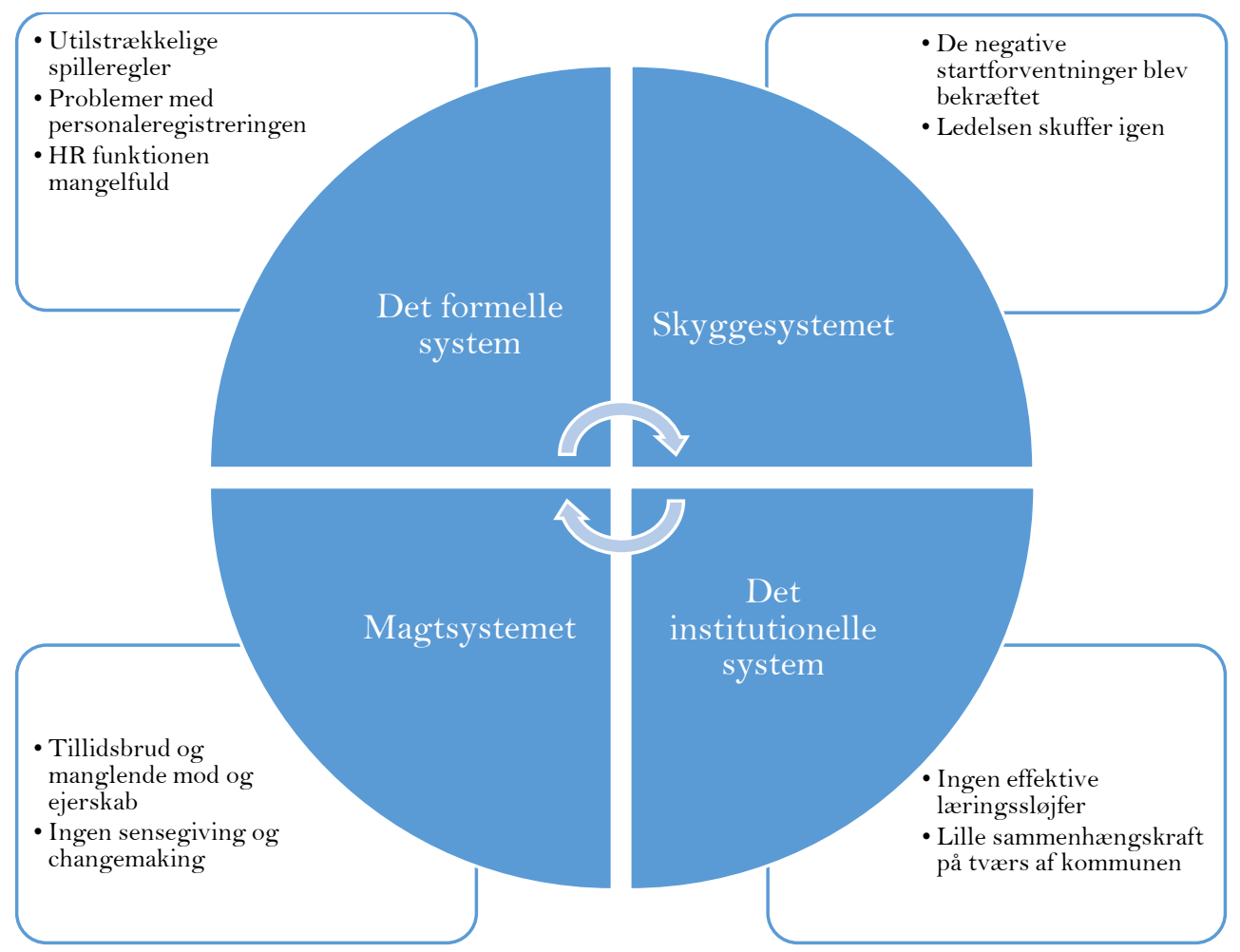

Figur 10: Casen viste mange barrierer for den kontinuerte andringsproces, som ikke blev ordentligt adresseret. 
Ledelsesstilen var en særlig problemstilling, specielt fra det politiske niveau. Listen Byfornyerne havde defineret deres rolle som kontrollant over for samtlige kommunens ansatte og havde 40 efterlønnere til gratis at gennemgå alt tilgængeligt materiale for at sikre, at der ikke blev lavet nogen fodfejl. Det betød, at organisationen i stor udstrækning led af korrekthedsbulimi. Man sikrede alt tre gange af frygt for at lave fejl. Byfornyerne holdt sig ikke tilbage, når det gjaldt at hænge enkeltpersoner ud længere nede i hierarkiet med navns nævnelse i avisen. Byfornyernes holdning blev af langt den overvejende del af de ansatte anset som den væsentligste barriere for projektets succes.

Med udgangspunkt i det foranstående samt casebeskrivelsen² vil jeg give følgende svar på de i casen stillede spørgsmål.

\section{E. Et svar på spørgsmålene}

\begin{tabular}{|l|l|}
\hline Spørgsmål. & Svar. \\
\hline $\begin{array}{l}\text { Hvordan kan konsulent- og } \\
\text { rådgivningsfirmaer sikre sig, at } \\
\text { opdragsgiveren ved hvad det er, han bestiller?, } \\
\text { ønskede løsning kan implementeres. } \\
\text { I casen var betingelsen, at magtsystemet ville } \\
\text { og kunne lede, med udgangspunkt i værdier } \\
\text { snarere end regler og hårde mål, samt at } \\
\text { magtsystemet kunne fungerer som } \\
\text { changemakere. }\end{array}$ \\
\hline $\begin{array}{l}\text { FRYSNING } \\
\text { Hvordan kan man sikre sig, at } \\
\text { bestillerorganisationen er rustet til at modtage } \\
\text { det, den har bestilt? }\end{array}$ & $\begin{array}{l}\text { Ved at gennemføre en foranalyse og udarbejde } \\
\text { en risikovurdering, som magtsystemet } \\
\text { efterfølgende forpligter sig på. Dette blev også } \\
\text { gjort i casen, men ejerskabet viste sig kun i } \\
\text { ord og ikke i handling. }\end{array}$ \\
\hline
\end{tabular}

\footnotetext{
${ }^{2}$ Se http://dx.doi.org/10.22439/sis.v33i4.5567
} 


\begin{tabular}{|c|c|}
\hline $\begin{array}{l}\text { Vil opdragsgiverne ikke blot finde et andet } \\
\text { firma, hvis konsulentfirmaet lægger afgørende } \\
\text { vægt på at få opdragsgiverne til at kommitte } \\
\text { sig til at spille en langt større rolle som } \\
\text { transformationsledere, end den, som de først } \\
\text { havde forestillet sig? }\end{array}$ & $\begin{array}{l}\text { Det er en erfaring, som jeg tror, alle de store } \\
\text { konsulentfirmaer har. }\end{array}$ \\
\hline $\begin{array}{l}\text { Hvorfor ser direktionen ikke sin egen adfærd } \\
\text { som noget, man skal ændre og følge op på? }\end{array}$ & $\begin{array}{l}\text { Kommunaldirektøren havde positive } \\
\text { erfaringer og forventninger fra et tilsvarende } \\
\text { projekt gennemført i den kommune, han } \\
\text { tidligere var ansat i. } \\
\text { Læringen her er, at det er problematisk at } \\
\text { overføre forventninger og erfaringer fra en } \\
\text { organisation til en anden. }\end{array}$ \\
\hline $\begin{array}{l}\text { Er det realistisk at satse på frisættelse, tillid } \\
\text { og ejerskab i en kultur, der er gennemsyret af } \\
\text { markant regelstyring, kontrol og korrektheds } \\
\text { bulimi? }\end{array}$ & $\begin{array}{l}\text { Det vil kun være realistisk, hvis magtsystemet } \\
\text { kan fungere som kompetente changemakere } \\
\text { jfr. Weick og Petersen \& Ågård }\end{array}$ \\
\hline $\begin{array}{l}\text { Kan man forvente, at mellemlederniveauet } \\
\text { træder frem i en sådan transformationsproces? } \\
\text { Hvad kan man gøre som modspil for at løse } \\
\text { disse paradokser? }\end{array}$ & $\begin{array}{l}\text { Kun hvis topledelsen er kommittet til } \\
\text { processen og vil praktisere talk the walk. } \\
\text { Processen burde have været suppleret med en } \\
\text { politisk ændringsproces for byråd og } \\
\text { direktion. }\end{array}$ \\
\hline $\begin{array}{l}\text { Er det rigtigt, at lederskab forudsætter, at } \\
\text { man kan høre, hvad organisationen siger om } \\
\text { sig selv? }\end{array}$ & $\begin{array}{l}\text { Ja: I modsat fald vil det blive lederskab med } \\
\text { bind for øjnene. }\end{array}$ \\
\hline $\begin{array}{l}\text { Hvordan sikrer lederne, at kommunikationen } \\
\text { nedefra ikke filtreres uhensigtsmæssigt, og bør } \\
\text { de tage den alvorligt, hvis man ikke er enig i } \\
\text { eller ikke kan lide det, man evt. hører? }\end{array}$ & $\begin{array}{l}\text { Man bør skabe en modtagerkanal koblet til } \\
\text { kilden og derefter undlade at argumentere } \\
\text { mod det, der bliver sagt. } \\
\text { Det medarbejderne siger, de oplever, er det de } \\
\text { oplever. }\end{array}$ \\
\hline
\end{tabular}




\begin{tabular}{|c|c|}
\hline $\begin{array}{l}\text { Hvad kan medarbejderne blive stolte af i en } \\
\text { splittet og demotiveret organisation? }\end{array}$ & $\begin{array}{l}\text { Det fortæller motivationsteorien }{ }^{3} \text { nemlig } \\
\text { følgende } 3 \text { betingelser: } \\
\text { 1. At have den nødvendige kontrol over eget } \\
\text { arbejde. } \\
\text { 2. At kunne blive dygtigere til det, man } \\
\text { laver. } \\
\text { 3. At det, man laver, har en værdi for dem, } \\
\text { der får ydelserne, } \\
\text { Dette peger netop på værdiledelse og på IY } \\
\text { styringsmodellen }\end{array}$ \\
\hline $\begin{array}{l}\text { Giver det nogen mening at opstille } \\
\text { succeskriterier, når man ikke har en realistisk } \\
\text { plan, der viser, hvordan man vil opnå dem? }\end{array}$ & $\begin{array}{l}\text { Nej - det er vel også historien bag de fleste } \\
\text { nytårsfortsætter, der ikke fortsætter januar ud. }\end{array}$ \\
\hline $\begin{array}{l}\text { Kan en realistisk plan være den, at dem, vi } \\
\text { delegerer opgaven til, vil sikre, at vi når de } \\
\text { succeskriterier, vi har opstillet? }\end{array}$ & $\begin{array}{l}\text { Nej, kun hvis magtsystemet er kommittet og } \\
\text { kan fungere som changemakers i processen. }\end{array}$ \\
\hline $\begin{array}{l}\text { Hvorfor reagerer magtsystemet ikke på det, } \\
\text { ændringen forudsætter af magtsystemet, } \\
\text { således som det, den kommunale selfie viste? }\end{array}$ & $\begin{array}{l}\text { Som Weick påpeger, så er magtsystemet og } \\
\text { medarbejderne to sider af samme mønt - } \\
\text { medarbejderne er utilfredse med } \\
\text { magtsystemet, og magtsystemet ser } \\
\text { medarbejderne som besværlige } \\
\text { brokkehoveder. }\end{array}$ \\
\hline $\begin{array}{l}\text { Er det muligt at reformere adfærden i } \\
\text { magtsystemet i et anarki? }\end{array}$ & $\begin{array}{l}\text { Ja, hvis den nødvendige del af } \\
\text { meningsdannende beslutningstagere kan } \\
\text { etablere en holdbar koalition og derefter følge } \\
\text { ESS strategien }{ }^{4} \text {, således som spilteorien } \\
\text { beskriver } \\
\text { Det så næsten ud til at være lykkedes på } \\
\text { byrådsseminaret, men koalitionen her var ikke } \\
\text { holdbar nok. }\end{array}$ \\
\hline $\begin{array}{l}\text { Er vi opmærksomme på betydningen af en } \\
\text { fælles vision? }\end{array}$ & $\begin{array}{l}\text { Min erfaring er, at vi mener, at en vision er } \\
\text { vigtig, men også at vi ikke har fornemmelse af }\end{array}$ \\
\hline
\end{tabular}

\footnotetext{
${ }^{3}$ Se Daniel Pink - Motivation - Den overraskende sandhed om, hvad der motiverer os.

${ }^{4}$ ESS strategien se The Evolution of cooperation.
} 


\begin{tabular}{|c|c|}
\hline & $\begin{array}{l}\text { dens manglende værdi, hvis den ikke er delt og } \\
\text { fælles. }\end{array}$ \\
\hline $\begin{array}{l}\text { Kan vi se, om den er delt eller blot en } \\
\text { "skuevision", som medarbejdere og medledere } \\
\text { ikke tager ejerskab af? }\end{array}$ & $\begin{array}{l}\text { Visionen her indebærer en anden ordens } \\
\text { læringsproces for organisationen. Testen på } \\
\text { om den er delt, kan derfor først ses et stykke } \\
\text { hen i implementeringsprocessen. }\end{array}$ \\
\hline $\begin{array}{l}\text { Hvad ville det have krævet, at gøre visionen i } \\
\text { casen til en fælles og delt vision? }\end{array}$ & $\begin{array}{l}\text { En bredere organisatorisk debat af formål, } \\
\text { implementering, risikofaktorer og forventet } \\
\text { effekt, inden kursets start }\end{array}$ \\
\hline $\begin{array}{l}\text { Hvorfor agerede magtsystemet ikke mere } \\
\text { markant på det organisatoriske selvbillede, } \\
\text { som gentagne gange blev tegnet under } \\
\text { projektforløbet? }\end{array}$ & $\begin{array}{l}\text { Man så primært medarbejderne og kulturen } \\
\text { som problemet, og man var blind for } \\
\text { magtsystemets rolle som kulturbærer. } \\
\text { Magtsystemets fortolkning af medarbejderne } \\
\text { var et spejl af medarbejdernes fortolkning af } \\
\text { magtsystemet }\end{array}$ \\
\hline $\begin{array}{l}\text { Hvordan burde magtsystemet have brugt } \\
\text { mobiliseringsmøderne til at skabe et ejerskab, } \\
\text { som kunne have sikret forankringen af den } \\
\text { ændring, man havde bestilt og igangsat? }\end{array}$ & $\begin{array}{l}\text { Ved at deltage i mobiliseringsmøderne og ved } \\
\text { at træde tydeligt frem og vise ejerskab til } \\
\text { forandringen. Det blev i øvrigt også efterlyst } \\
\text { på møderne. }\end{array}$ \\
\hline \multicolumn{2}{|c|}{ REBALANCERING } \\
\hline $\begin{array}{l}\text { I hvilken udstrækning kan } \\
\text { organisationsudvikling, baseret på et train the } \\
\text { trainer forløb, lykkes, når trainerner ikke har } \\
\text { praktisk organisationsudviklings-erfaring, og } \\
\text { når de ikke må intervenere i feltet efter } \\
\text { kurserne? }\end{array}$ & $\begin{array}{l}\text { Forløbet kan i bedste fald alene skabe en } \\
\text { interesse hos forskellige aktører. Den } \\
\text { efterfølgende intervention og implementering } \\
\text { er overladt til lokale initiativer. } \\
\text { Forventningen fra opdragsgiverne var, at } \\
\text { optøningen ville ske af sig selv. Der var ikke } \\
\text { planlagt postimplementeringsaktiviteter. }\end{array}$ \\
\hline $\begin{array}{l}\text { Er vi opmærksomme nok på, hvornår et } \\
\text { kursus blot vil blive indkapslet træning? }\end{array}$ & $\begin{array}{l}\text { Det burde vi vel være, nemlig at det, der } \\
\text { udfolder sig på kurserne, efterfølgende bliver } \\
\text { sat i spil i dagligdagen. }\end{array}$ \\
\hline $\begin{array}{l}\text { Hvad skal der til, for at kurserne } \\
\text { internaliseres? }\end{array}$ & $\begin{array}{l}\text { At de lokale ledere og mellemledere følger } \\
\text { processen til dørs. }\end{array}$ \\
\hline
\end{tabular}




\begin{tabular}{|c|c|}
\hline $\begin{array}{l}\text { Listen over spilleregler fra byrådsseminaret } \\
\text { lyder som et udpluk at ledelseskommissionens } \\
\text { anbefalinger. Hvad skal der til, for at det ikke } \\
\text { kun bliver en ønskeliste uden bund i } \\
\text { virkeligheden? }\end{array}$ & $\begin{array}{l}\text { At der er nok meningsskabende aktører i } \\
\text { magtsystemet, som i fællesskab tør sætte sig } \\
\text { selv på spil. }\end{array}$ \\
\hline $\begin{array}{l}\text { Hvordan kunne byrådet i længere tid leve med } \\
\text { en arbejdssituation som den her beskrevne? }\end{array}$ & $\begin{array}{l}\text { En velkendt psykologisk mekanisme, man } \\
\text { reagerer først overfor fx voldsmænd, når den } \\
\text { første modige træder frem. Hvem er den første } \\
\text { modige i byrådet? }\end{array}$ \\
\hline $\begin{array}{l}\text { Er Kanters pointer om manglende tiltro et } \\
\text { godt svar? }\end{array}$ & $\mathrm{Ja}$, det viser seminaret med byrådet. \\
\hline $\begin{array}{l}\text { Og hvis ja, hvordan slipper man så ud af } \\
\text { beslutningskulturen, når byrådet er toppen af } \\
\text { magtsystemet? }\end{array}$ & $\begin{array}{l}\text { Problemet med seminaret var, at Byfornyerne } \\
\text { ikke deltog. Vi fik derfor ikke den nødvendige } \\
\text { konfrontation og fælles byggeproces med det } \\
\text { samlede byråd inklusiv Byfornyerne. }\end{array}$ \\
\hline $\begin{array}{l}\text { Hvad gør man, hvis byrådet, som den øverste } \\
\text { del af magtsystemet, er et taberhold? }\end{array}$ & $\begin{array}{l}\text { Den første nødvendige opgave er at skabe } \\
\text { gensidig tillid mellem parterne. Den } \\
\text { manglende indbyrdes tillid var formentlig } \\
\text { byrådets største problem. }\end{array}$ \\
\hline \multicolumn{2}{|c|}{ OPTØNING } \\
\hline $\begin{array}{l}\text { Bekræfter virkningsevalueringen Torben Beck } \\
\text { Jørgensens konklusioner om initiativer i } \\
\text { værdibrede kommuner? Hvis ja hvordan skal } \\
\text { vi så forholde os til det? }\end{array}$ & $\begin{array}{l}\text { Ja, det bekræftede virkningsevalueringen. } \\
\text { Oplægget med at blande kursusdeltagerne fra } \\
\text { de forskellige forvaltninger var ok, men den } \\
\text { efterfølgende lokale implementering } \\
\text { manglede, primært fordi magtsystemet } \\
\text { svigtede. }\end{array}$ \\
\hline $\begin{array}{l}\text { Hvordan kan vi få forskellige fagligheder til at } \\
\text { respektere hinanden og samarbejde bedre? }\end{array}$ & $\begin{array}{l}\text { Ved at skabe en dialog imellem dem, således } \\
\text { som det blev forsøgt på kurserne. } \\
\text { At arbejde med kollagemetaforen kunne være } \\
\text { et godt udgangspunkt. }\end{array}$ \\
\hline $\begin{array}{l}\text { Hvorfor lader byrådet sig føre tilbage til den } \\
\text { adfærd, man som byrådsmedlem ikke kan lide, }\end{array}$ & $\begin{array}{l}\text { Formentlig på grund af manglende tillid i } \\
\text { byrådet, og fordi det krævede et stort }\end{array}$ \\
\hline
\end{tabular}




\begin{tabular}{|c|c|}
\hline $\begin{array}{l}\text { oven i købet når man ved, det skader } \\
\text { kommunen? }\end{array}$ & $\begin{array}{l}\text { kommitment at forsvare et stort ikke ventet } \\
\text { underskud. }\end{array}$ \\
\hline $\begin{array}{l}\text { Er en god skandale det vigtigste, hvis man vil } \\
\text { øge egne politiske magtmidler? }\end{array}$ & $\begin{array}{l}\text { Ja, egen succes er god, men andres fiasko er } \\
\text { ikke at foragte - som man siger. }\end{array}$ \\
\hline $\begin{array}{l}\text { Kan pressen være bekendt at gengive alt, hvad } \\
\text { den får serveret? }\end{array}$ & $\begin{array}{l}\text { Nej, ikke hvis det blot omfatter at præsentere } \\
\text { alle mulige uredigerede partindlæg. }\end{array}$ \\
\hline $\begin{array}{l}\text { Hvad skal der til i en politisk forsamling, hvor } \\
\text { kulturen i lang tid har været fnidder, } \\
\text { nulsumsspil, skjulte dagsordner etc., for at } \\
\text { man kan skabe en fælles fremtid og etablere et } \\
\text { tillidsforhold til hinanden? }\end{array}$ & 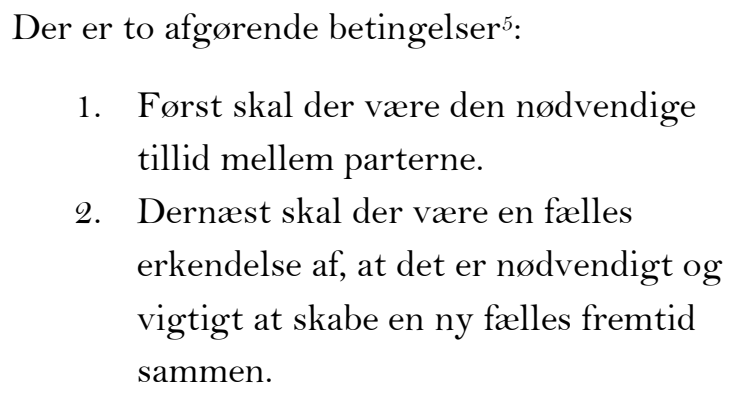 \\
\hline $\begin{array}{l}\text { Er det nok alene at formulere fælles } \\
\text { spilleregler, som dem, der blev lagt op til på } \\
\text { byrådsseminaret? }\end{array}$ & $\begin{array}{l}\text { Nej, ikke når adfærden i magtsystemet netop } \\
\text { var, at bryde spillereglerne hver gang, dette } \\
\text { synes formålsagtigt. }\end{array}$ \\
\hline $\begin{array}{l}\text { Har Ackoff ret i det han skriver? Og lægger } \\
\text { universiteter og læreanstalter for meget vægt } \\
\text { på videnskab og teknologi og for lidt vægt på } \\
\text { værdier og holdninger? }\end{array}$ & $\begin{array}{l}\text { Ja, her er det en manglende fælles holdning til, } \\
\text { hvilken balance mellem styringsmodeller, vi } \\
\text { bør satse på fremover, der er problemet. }\end{array}$ \\
\hline $\begin{array}{l}\text { Når vores projekter går galt, er det så ofte på } \\
\text { grund af holdninger og de begrænsninger, det } \\
\text { giver i vores erkendelser? }\end{array}$ & $\begin{array}{l}\text { Næsten alle de projekter, jeg har været } \\
\text { præsenteret for i mit 50-årige konsulent- og } \\
\text { vejleder liv, har altid været kendetegnet alene } \\
\text { ved et enkelt forandringsperspektiv, et formål } \\
\text { og en retning. Jeg har stadig til gode at se et } \\
\text { projekt - eller en projektportefølje, som i } \\
\text { udgangspunktet indeholder flere } \\
\text { forandringsperspektiver og flere synkrone } \\
\text { udviklingsspor. }\end{array}$ \\
\hline $\begin{array}{l}\text { Og hvis ja, hvordan kunne vi have håndteret } \\
\text { det? }\end{array}$ & $\begin{array}{l}\text { Projektet burde have haft et indledende spor } \\
\text { for opbygning og test af ejerskab i } \\
\text { magtsystemet, og hvis det ikke kunne lykkes }\end{array}$ \\
\hline
\end{tabular}

${ }^{5}$ Se fx Beyer et all. Samarbejde mellem organisationer 


\begin{tabular}{|l|l|}
\hline & $\begin{array}{l}\text { at skabe det, burde projektet have været } \\
\text { opgivet. }\end{array}$ \\
\hline
\end{tabular}

\section{Referencer}

Ackoff, Russel L. (1976): En ny fremtid formes - systemteorien anvendt på samfundsproblemer. København: Nyt Nordisk Forlag, Arnold Busck. København.

Atkinson, John, Emma Loftus \& John Jarvis (2015): "The Art of Change Making” The Leadership Centre, Local Government House, Smith Square, London ISBN: 978-0-9931400-9-9 https://www.leadershipcentre.org.uk/wp-content/uploads/2016/02/The-Art-of-ChangeMaking.pdf

Axelrod, Robert (1984): "The Evoution of Cooperation", New York; Basic Books

Beyer, Peter (2013): "Implementering af tillidsbaseret regulering - En fjern tanke eller en nar fremtid" Arbejdspapir CBS.

https://www.cbs.dk/files/cbs.dk/arbejdsrapport-implementering-af-tillidsfunderet-regulering.pdf

Beyer, Peter \& Kim Peiter Jørgensen; (2008) "Samarbejde mellem organisationer - collaborative engineering metoden" Samfundslitteratur; København

Beyer, Peter (2016); Vardibaseret transformationsledelse; Karnov, Københacn

Beyer, Peter (2018): "Kampen om den organisatoriske selvfortelling" i Samfundslederskab i Skandinavien 2018 nr. 4. http://dx.doi.org/10.22439/sis.v33i4.5567

Beyer, Peter (2018): "Transformationsstrategier”; Samfundslitteratur; København.

Borum, Finn (2013): "Strategier for Organisationsandring”; Handelshøjskolens forlag; København.

Kanter, Rosabeth Moss (2005): Confidence. Random House Business Books.

Lent, Adam \& Jessica Studdert (2017): “A changemaking vision for local government. An NLGN think piece. http://www.nlgn.org.uk/public/wp-content/uploads/A-Changemaking-Vision-ofLocal-Government.pdf 
Beyer / Når man køber ...

Lerborg, Leon (2010): “Styringsparadigmer I den offentlige sektor” Jurist og økonomforbundets forlag; København.

Lipsky, Michael (1980): “Street-level bureaukracy: Dilemmas of the Individual in Public Service”; New York; Russel Sage Foundation

Mac, Anita \& Sabine Madsen red. (2017): "Forandringsforståelse: Balance mellem proces og resultat" Samfundslitteratur; København.

Meister, David (2007); “Are We In This Together? The Preconditions For Strategy”. https://davidmaister.com/articles/are-we-in-this-together-the-preconditions-for-strategy/

Pedersen, John Storm og Peter Aagaard (2013): "Fra åben konflikt til symbiotisk evolution: Hvordan offentlige ledere forener fagprofessionel autonomi og hård budgetdisciplin” Økonomistyring og Informatik; 29 årgang 2013/2014 nr. 1; København.

Pink Daniel H. (2009): Drive: The Surprising Truth About What Motivates Us. Riverhead Hardcover Weick, Karl E. \& R. E. Quinn (1999): "Organizational Change and Development". Annual Review of Psychology. 50: 361-386. https://doi.org/10.1146/annurev.psych.50.1.361

Weick, Karl E. (1995): Sensemaking in Organizations. Sage Publications, USA. 